Copyright by the Ecological Society of America. K. S. Simon, E. F. Benfield, and S. A. Macko 2003. FOOD WEB STRUCTURE AND THE ROLE OF EPILITHIC BIOFILMS IN CAVE STREAMS. ECOlogy 84:2395-2406. http://dx.doi.org/10.1890/02-334

Ecology, 84(9), 2003, pp. 2395-2406

(c) 2003 by the Ecological Society of America

\title{
FOOD WEB STRUCTURE AND THE ROLE OF EPILITHIC BIOFILMS IN CAVE STREAMS
}

\author{
K. S. Simon, ${ }^{1,3}$ E. F. Benfield ${ }^{1}$ And S. A. MACKO ${ }^{2}$ \\ ${ }^{1}$ Department of Biology, Virginia Polytechnic Institute and State University, Blacksburg, Virginia 24061 USA \\ ${ }^{2}$ Environmental Sciences Department, University of Virginia, Charlottesville, Virginia 22903 USA
}

\begin{abstract}
Cave stream food webs rely exclusively on detritus from the surface for energy and represent a heterotrophic end point in the continuum of stream types. Both dissolved organic matter (DOM) and particulate organic matter, and associated microbes, are available in caves, but the relative importance of these foods is unclear. We examined trophic structure and the roles of particulate organic matter and DOM retained in epilithic biofilms in three cave streams using natural abundance isotopes $\left({ }^{13} \mathrm{C}\right.$ and $\left.{ }^{15} \mathrm{~N}\right)$ and ${ }^{13} \mathrm{C}$ tracer additions. Natural abundance ${ }^{15} \mathrm{~N}$ ratios showed that cave animals occupied two trophic levels: primary consumers and predators. Epilithic biofilms and animals were highly enriched in ${ }^{15} \mathrm{~N}$, suggesting that dissolved organic matter from surface soils was incorporated into epilithon and supported stream food webs, even when coarse particulate organic matter (CPOM) from the surface was abundant. We conducted 28 -day ${ }^{13} \mathrm{C}$-acetate tracer additions to trace the use of epilithon carbon in the food webs. The $\operatorname{tracer}{ }^{13} \mathrm{C}$ acetate was rapidly taken up in the streams at uptake velocities $\left(0.5-22.8 \times 10^{-5} \mathrm{~m} / \mathrm{s}\right)$ and uptake rates $(0.04-$ $0.23 \mathrm{mg} \mathrm{m}^{-2} \mathrm{~h}^{-1}$ ) similar to those in surface streams. Epilithon was highly labeled and epilithon turnover time was relatively long (10.0-16.7 d), showing that $C$ from DOM was immobilized in biofilms and thus available to invertebrates, which also became labeled with tracer by the end of the experiment. Several snails (Fontigens tartarea, Gyraulus parvus, and Physa sp.) that fed directly on epilithon were highly enriched with tracer ${ }^{13} \mathrm{C}$. Other primary consumers (Gammarus minus and Caecidotea holsingeri) fed on a combination of epilithon and fine particulate organic matter. Predators in the streams (Stygobromus emarginatus, S. spinatus, and Macrocotyla hoffmasteri) also became labeled with ${ }^{13} \mathrm{C}$, indicating that biofilm $\mathrm{C}$ was passed through the entire food web. This study shows that DOC and epilithic biofilms are important energy sources for stream communities even when $\mathrm{CPOM}$ is an abundant resource.
\end{abstract}

Key words: ${ }^{13} \mathrm{C}$; cave; epilithic biofilms; food webs; microbial loop; ${ }^{15} \mathrm{~N}$; stable isotope; stream.

\section{INTRODUCTION}

Streams range from unshaded, highly autotrophic systems to heavily shaded, heterotrophic systems. While photoautotrophs are considered important to food webs in unshaded streams, forest streams have been thought to rely mostly on detritus as an energy source because autochthonous production is low compared to the availability of detritus (e.g., Fisher and Likens 1973, Vannote et al. 1980). Coarse particulate organic matter (CPOM), primarily leaves and wood, from riparian vegetation can fuel stream food webs (Fisher and Likens 1973, Minshall et al. 1983), and communities in shaded streams are tightly linked to the availability of CPOM (Wallace et al. 1999). Consumers may eat CPOM or use it indirectly by grazing microbial films growing on CPOM (Cummins 1974). However, it has become increasingly clear that other food web components of much smaller biomass, such as algae

Manuscript received 3 June 2002; revised 22 December 2002; accepted 23 January 2003. Corresponding Editor: S. Findlay.

${ }^{3}$ Present address: Department of Biology, James Madison University, Harrisonburg, Virginia 22807 USA.

E-mail: simonks@jmu.edu
(McCutchan and Lewis 2002) and bacteria (Hall et al. 2000), can contribute significantly to food webs of shaded streams. Biofilms fueled by dissolved organic carbon (DOC) clearly contribute to stream food webs (Meyer 1994, Hall and Meyer 1998), but their importance in relation to availability of other foods is not clear.

Cave streams are a heterotrophic end point in the continuum of stream types. Because the absence of sunlight precludes photosynthetic primary production in caves, cave stream food webs rely exclusively on particulate detritus or DOC originating from the surface (Culver 1985). While chemoautotrophic pathways can fuel some cave food webs, few caves with significant inputs of chemicals needed by chemoautotrophs are known (e.g., Sarbu et al. 1996, Hose et al. 2000). Some cave streams are connected to the surface by relatively large openings that permit entrance of CPOM, which should be a high-quality food source in the energypoor cave environment. In contrast, percolation-fed streams import only fine particulate organic matter (FPOM) and DOC. The relative importance of the various primary energy sources in caves is not clear, but important because food limitation has been a strong 
TABLE 1. Stream discharge, width, standing stocks of epilithon, and fine, coarse, and suspended particulate organic matter (FPOM, CPOM, and SPOM, respectively), and dissolved organic carbon (DOC) in the study streams.

\begin{tabular}{|c|c|c|c|}
\hline Variable & Jones Canyon & Sively 3 & Sively 2 \\
\hline Discharge (L/s) & 0.03 & 1.19 & 0.43 \\
\hline Width (m) & 0.2 & 1.0 & 0.3 \\
\hline Epilithon (g AFDM $/ \mathrm{m}^{2}$ ) & $(1.7)^{\mathrm{a}}$ & $(0.1)^{\mathrm{b}}$ & $(0.4)^{\mathrm{ab}}$ \\
\hline FPOM (g AFDM/m²) & $(9.5)^{\mathrm{a}}$ & $(7.4)^{\mathrm{a}}$ & $(16.8)^{\mathrm{a}}$ \\
\hline CPOM (g AFDM/m²) & $0.0 \quad(0.0)^{\mathrm{a}}$ & $0.1 \quad(0.1)^{\mathrm{ab}}$ & $17.8(6.2)^{\mathrm{b}}$ \\
\hline SPOM (mg AFDM/L) & $0.96(0.36)^{\mathrm{a}}$ & $0.71(0.07)^{\mathrm{a}}$ & $1.22(0.28)^{\mathrm{a}}$ \\
\hline $\mathrm{DOC}(\mathrm{mg} / \mathrm{L})$ & $1.2(0.1)^{\mathrm{a}}$ & $3.4(0.6)^{\mathrm{b}}$ & $1.8(0.2)^{\mathrm{a}}$ \\
\hline
\end{tabular}

Notes: Values in parentheses are one standard error. Means within each row with the same superscript letter are not significantly different (ANOVA, $P>0.05$ ).

force in the evolution and ecology of cave animals (Culver 1982). Cave streams also may be useful for understanding detritus processing in streams by serving as model detritus-driven stream food webs. Compared to surface streams, cave streams have: (1) simpler food webs fueled solely by detritus; (2) similar physical attributes (substrate, flow, riffle-pool sequence); (3) similar community trophic structure (detritus, biofilms, collectors, shredders, scrapers, predators); (4) relatively stable environments; and (5) inputs of organic matter that vary among streams and over time.

Studying detrital pathways in surface systems is complicated by the presence of both autotrophic and heterotrophic pathways, speciose food webs, and complex detrital input. Stable isotope natural abundances and tracers have emerged as useful tools for untangling complex food webs in many ecosystems, including streams. Natural abundance studies rely on the characteristic fractionation of isotopes, typically of $\mathrm{C}$ or $\mathrm{N}$, during assimilation. This method has successfully identified consumer-food relationships in surface streams (e.g., Rounick et al. 1982, Peterson et al. 1993), but the approach relies on distinct differences in the isotopic signature of specific foods, which often do not occur. Tracer studies are useful because labeled compounds can be followed through food webs (e.g., Peterson et al. 1997, Hall et al. 1998, Hall and Meyer 1998). Studies combining natural abundance ratios and tracer addition (e.g., Mulholland et al. 2000) have proven particularly useful by taking advantage of the benefits of both approaches.

In this study, we used natural abundance ratios of $\mathrm{C}$ and $\mathrm{N}$ in conjunction with ${ }^{13} \mathrm{C}$ tracer additions to study food web structure and the importance of various energy sources in three cave stream food webs with differing terrestrial detritus input. Our goals were to: (1) clarify the trophic base and feeding relationships among animals in cave streams; (2) examine the role of microbial carbon in cave stream food webs; (3) investigate the influence of CPOM on cave stream food webs by comparing cave streams with differing particulate detritus input.

\section{Methods}

Study sites

We conducted the study in early spring 1999 in Organ Cave, Greenbrier County, West Virginia. Organ cave contains $>60 \mathrm{~km}$ of passage and a stream network that drains an $8.1-\mathrm{km}^{2}$ basin (Stevens 1988). Streams in the cave range from first to third order and vary in connectivity to the surface. Some streams are directly connected to the surface by large openings and consequently receive allochthonous CPOM (leaves and wood), FPOM, and DOM. Other streams are fed only by water that percolates through overlying soil and bedrock and receive DOM and FPOM, but not CPOM. There is little evidence of chemoautotrophic production or guano input to these streams, so CPOM, FPOM, and DOM are the only known sources of energy for the stream food webs.

We chose three streams, Jones Canyon, Sively 3, and Sively 2, which span the range of CPOM input to Organ Cave streams and contain the bulk of the aquatic species found in the drainage network. These small, firstorder streams flow over bedrock, gravel, and silt. Jones Canyon is fed strictly by percolating water and received no CPOM (Table 1 ). Sively 3 is weakly connected to the surface and contained a small amount of CPOM, generally small pieces of wood. Sively 2 received the largest amount of CPOM from the surface, including leaf and wood fragments.

The streams contain obligate (stygobite) and facultative (stygophile) cave animals as well as some surface (epigean) species, although not all animals were present in each stream. Stygobitic animals found included amphipod (Stygobromus emarginatus and S. spinatus) and isopod (Caecidotea holsingeri) crustaceans, a planarian (Macrocotyla hoffmasteri), and a snail (Fontigens tartarea). Gammarus minus, a stygophilic amphipod found in surface streams and cave streams, occurs in Sively 3 and Sively 2 only, presumably as a result of its invasion history (Culver et al. 1994). Eurycea bislineata, a stygophilic salamander, was occasionally seen in Sively 3 and Sively 2. Epigean invertebrates often found in the streams include snails $(G y$ - 
raulus parvus and Physa sp.) and caddisflies (Dolophilodes sp.).

\section{Organic matter standing stocks}

Standing stocks of epilithon were determined from 10 rocks collected on 11 November 2002 in each stream. The rocks were returned to the laboratory, scrubbed in a small amount of water, and filtered onto a preashed glass fiber filter (Gelman AE, Pall Corporation, East Hills, New York, USA). The filters were dried $\left(60^{\circ} \mathrm{C}\right)$, weighed, ashed $\left(550^{\circ} \mathrm{C}\right)$, wetted, dried $\left(60^{\circ} \mathrm{C}\right)$, and reweighed to calculate ash-free dry mass (AFDM). Suspended particulate organic matter (SPOM) was collected on 5-11 dates during 19981999. In each stream, $5 \mathrm{~L}$ of water was filtered onto a preashed glass fiber filter and analyzed for AFDM. Values for FPOM and CPOM were estimated as described in Simon and Benfield (2001). DOC concentration in each stream was measured weekly during the ${ }^{13} \mathrm{C}$ additions. DOC samples were filtered (Gelman AE) and frozen until analysis on a Model 700 TOC analyzer (O.I. Corporation, College Station, Texas, USA).

\section{${ }^{13} \mathrm{C}$ tracer release}

We used a tracer addition of $\mathrm{Na}-1-{ }^{13} \mathrm{C}$-acetate to label microbial films in each stream and trace microbial $\mathrm{C}$ as it moved through the food webs. Most of the ${ }^{13} \mathrm{C}$ uptake was probably by bacteria because fungal halfsaturation constants for labile DOC are $\sim 0.1-1 \mathrm{mmol} /$ L (Newell 1984, Hall and Meyer 1998), which is above the $\sim 0.1 \mu \mathrm{mol} / \mathrm{L}$ acetate concentration we maintained in our streams. Bacteria, on the other hand, have halfsaturation constants of $\sim 0.001 \mu \mathrm{mol} / \mathrm{L}$ (Newell 1984), well below the acetate concentration we created in the stream. Some abiotic sorption of the label to biofilms probably occurred; however, Hall and Meyer (1998) found abiotic sorption of ${ }^{13} \mathrm{C}$ acetate to stream sediments was minimal during similar releases in surface streams.

We used Marriotte bottles containing ${ }^{13} \mathrm{C}$ acetate dissolved in deionized $\mathrm{H}_{2} \mathrm{O}$ to deliver ${ }^{13} \mathrm{C}$ to the stream at a concentration of $\sim 1 \mu \mathrm{g}^{13} \mathrm{C} / \mathrm{L}(\sim 7 \mu \mathrm{g}$ acetate/L) for 28 d from 22 April to 20 May 1999. Acetate drip rate and injectate concentration were adjusted every other day to maintain a constant ${ }^{13} \mathrm{C}$ concentration during the release according to changes in stream discharge. Discharge was measured by multiplying stream cross-sectional area by velocity, measured with a flow-meter, at the downstream end of the study reach in Sively 2 and Sively 3. We measured discharge in Jones Canyon by directing the entire stream flow into a graduated cylinder with a piece of metal flashing for $30 \mathrm{~s}$. There should have been no carbon enrichment effect caused by the acetate release because the acetate DOC addition to each stream was small relative to background DOC $(0.06,0.03$, and $0.11 \%$ of background in Sively 2 , Sively 3, and Jones Canyon, respectively).

\section{Sample collection, processing, and analysis}

One day prior to the release, we collected detrital and invertebrate samples along a 55-65 m reach in each stream for isotope analysis. We used these samples for natural abundance $\delta^{13} \mathrm{C}$ analysis and to backgroundcorrect samples collected during and after our ${ }^{13} \mathrm{C}$ release. We used samples collected from all dates during our study for natural abundance $\delta^{15} \mathrm{~N}$ analysis. Triplicate samples of epilithon, FPOM, and larger invertebrates were taken upstream, midstream, and downstream of the reach. Composite samples of leaves, wood scrapings, and animals (5-15 individuals) which were too small for individual analysis (Fontigens, Gyraulus, Physa, Macrocotyla, and S. spinatus) were also collected throughout the study reach. Eurycea was rare in the streams and only single individuals were found in Sively 2 and Sively 3 prior to the release. A small piece of tail was clipped from each salamander and the salamander was then released.

In each stream we established stations 5, 10, 20, 40, and 55-65 $\mathrm{m}$ downstream of the release point for sample collection at the end of the ${ }^{13} \mathrm{C}$ release. After $28 \mathrm{~d}$, composite samples of 3-15 detrital or animal samples were collected within $2 \mathrm{~m}$ upstream or downstream of each station. The release was then stopped and collections were made again at the same stations 2 and $12 \mathrm{~d}$ after the release was stopped to measure the loss of tracer ${ }^{13} \mathrm{C}$ from each compartment.

At each station, epilithon was collected by brushing 3-5 rocks with a nylon brush in a small amount of water. FPOM was collected from five random locations at each station from the top $1 \mathrm{~cm}$ of the stream bed using a turkey baster. The FPOM slurry was then passed through a $1-\mathrm{mm}$ sieve in the field. In the laboratory, the epilithon and FPOM slurries were filtered onto preashed $0.45-\mu \mathrm{m}$ glass fiber filters and rinsed five times with deionized water to remove any loosely bound ${ }^{13} \mathrm{C}$ acetate. Epilithon and FPOM were scraped from the filters, taking care not to include filter particles in the sample, and placed into glass vials. Because cave sediments contain large amounts of inorganic $\mathrm{C}$ as $\mathrm{CaCO}_{3}$, a few drops of $30 \% \mathrm{HCl}$ were added to each epilithon and FPOM sample to drive off any inorganic C. At each station, several leaf pieces were collected by hand and the soft outer layer of 3-5 wood pieces was scraped with a knife. Leaves and wood were rinsed five times with deionized water and placed in glass vials. All organic matter samples were then dried at $40^{\circ} \mathrm{C}$.

Invertebrates were collected by hand, returned live to the laboratory, and kept at ambient stream temperature for $24 \mathrm{~h}$ to allow animals to clear most of their gut contents. Invertebrates were then rinsed five times with deionized water and dried at $40^{\circ} \mathrm{C}$. Snails were treated with a few drops of $30 \% \mathrm{HCl}$ to remove inorganic $\mathrm{C}$ in their shells before drying. Not all taxa 
could be collected at every station on given dates, so not all taxa are evenly represented in our samples.

Dried organic matter and animal samples were ground to a fine powder with a glass rod and the $\delta^{15} \mathrm{~N}$ and $\delta^{13} \mathrm{C}$ of each sample were determined on a Micromass Optima isotope ratio mass spectrometer (Waters Corporation, Milford, Massachusetts, USA) coupled with an elemental analyzer, with an overall precision better than $0.2 \%$. For each sample, the $\delta^{13} \mathrm{C}$ and $\delta^{15} \mathrm{~N}$ values were calculated as

$$
\delta\left({ }^{13} \mathrm{C} \text { or }{ }^{15} \mathrm{~N}\right)=\left(\left[R_{\text {sample }} / R_{\text {standard }}\right]-1\right) \times 1000
$$

where $R$ is the ${ }^{13} \mathrm{C} /{ }^{12} \mathrm{C}$ or ${ }^{15} \mathrm{~N} /{ }^{14} \mathrm{~N}$ ratio.

We used natural abundance $\delta^{15} \mathrm{~N}$ to analyze feeding relationships assuming an enrichment of 2-5\% between consumers and their food (Post 2002). We calculated the ratio of tracer $\delta^{13} \mathrm{C}$ in a consumer to tracer $\delta^{13} \mathrm{C}$ in potential food to determine potential feeding relationships (Mulholland et al. 2000). The ratio should equal 1.0 if organisms feed exclusively on one food and if the organism's $\mathrm{C}$ is in isotopic equilibrium with its food. (The trophic fractionation effect is removed by subtracting background values.) Ratios $<1.0$ indicate the animal used a less enriched food source or had not reached isotopic equilibrium. Ratios $>1.0$ indicate an organism used a more enriched food source or a more enriched subfraction of the food resource. Ratios at each station where both consumers and food were labeled above background on day 28 were averaged to calculate ratios for each consumer-food source pair.

\section{${ }^{13} \mathrm{C}$ acetate transport and uptake}

We calculated the acetate uptake length in each stream using the slope of the linear regression of $\ln \left(\delta^{13} \mathrm{C}\right)$ of epilithon vs. distance downstream $(x)$ :

$$
\ln \left(\delta^{13} \mathrm{C}_{x}\right)=\ln \left(\delta^{13} \mathrm{C}_{0}\right)-k_{\mathrm{L}} x
$$

where $\delta^{13} C_{x}$ is the background-corrected epilithon $\delta^{13} \mathrm{C}$ value at distance $x$ below the injection site on day 28 (Hall and Meyer 1998). Only sites whose $\delta^{13} \mathrm{C}$ values were above background levels were used in the regressions. ${ }^{13} \mathrm{C}$ uptake length $\left(S_{\mathrm{w}}\right)$, the average distance ${ }^{13} \mathrm{C}$ acetate traveled downstream before uptake, was calculated as the inverse of the slope $\left(k_{\mathrm{L}}\right)$ (Newbold et al. 1981). We used epilithon for calculations because it was most highly labeled, should represent the primary point of ${ }^{13} \mathrm{C}$ uptake in the stream, and should not be displaced downstream under normal flow because it is attached to rocks. We also calculated uptake lengths using snails (Fontigens in Jones Canyon and Sively 2 and G. parvus in Sively 3) to compare to epilithon $S_{\mathrm{w}}$. Uptake lengths were compared among streams by analysis of covariance (ANCOVA) with a dummy variable technique (Kleinbaum et al. 1988).

Because $S_{\mathrm{w}}$ is sensitive to stream velocity and depth and our streams varied in size, we calculated ${ }^{13} \mathrm{C}$-acetate uptake velocity $\left(V_{\mathrm{f}}, \mathrm{m} / \mathrm{s}\right)$ as

$$
V_{\mathrm{f}}=Q /\left(w \times S_{w}\right)
$$

where $Q$ is the average stream discharge $\left(\mathrm{m}^{3} / \mathrm{s}\right)$ during the release, $w$ is the average stream width $(\mathrm{m})$, and $S_{w}$ is the ${ }^{13} \mathrm{C}$ uptake length calculated from epilithon or snails (Stream Solute Workshop 1990).

${ }^{13} \mathrm{C}$ uptake rate $\left(U, \mathrm{mg} \mathrm{m}^{-2} \mathrm{~h}^{-1}\right)$, the amount of ${ }^{13} \mathrm{C}$ removed from the water per unit area and time, in each stream was calculated as follows:

$$
\sum_{x=1}^{20} U_{x}=\left(C_{x} \times Q \times 3600 \mathrm{~s} / \mathrm{h}\right) / S_{w}
$$

where $C_{x}$ is the concentration of acetate ${ }^{13} \mathrm{C}$ (in $\mathrm{mg} / \mathrm{L}$ ) at each meter $(x)$ below the release site, $Q$ is the average stream discharge, in $\mathrm{L} / \mathrm{s}$, during the release, and $S_{w}$ is the ${ }^{13} \mathrm{C}$ uptake length based on epilithon (Newbold et al. 1981, Hall and Meyer 1998). $C_{x}$ was calculated using $C_{0}$ (average ${ }^{13} \mathrm{C}$ concentration at the release site) and $S$ in Eq. 3. $U_{x}$ was summed for a $20-\mathrm{m}$ reach in each stream and divided by the area of each stream reach to determine ${ }^{13} \mathrm{C}$ acetate uptake per square meter per hour. We used a $20-\mathrm{m}$ reach in the calculation because it was the maximum distance in which epilithon was reliably labeled above background in each stream.

We estimated epilithon $\mathrm{C}$ turnover time $\left(T_{\mathrm{t}}\right)$ using the loss of tracer $\delta^{13} \mathrm{C}$ in epilithon between 2 and 12 days after the release was stopped. We assumed a logarithmic decline in the ${ }^{13} \mathrm{C}$ label and calculated $T_{\mathrm{t}}$ as 1/slope for the regression of $\delta^{13} \mathrm{C}$ vs. time for each station. For each stream, $T_{\mathrm{t}}$ values were calculated for each station and then averaged. At the end of the additions, we determined the amount of ${ }^{13} \mathrm{C}$ retained in epilithon, CPOM, and FPOM in each stream. The ${ }^{13} \mathrm{C}$ retained in each compartment was calculated by integrating ${ }^{13} \mathrm{C}$ in each compartment over distance on the final day of the additions (Mulholland et al. 2000).

\section{RESULTS}

Organic matter standing stocks

FPOM was the largest source of organic matter in all three streams (Table 1). Epilithic biomass was relatively small, and lowest in Sively 3. CPOM was absent in Jones Canyon, low in Sively 3, and relatively abundant in Sively 2. Suspended POM concentration was similar in all streams (Table 1). DOC concentration was similar in Jones Canyon and Sively 2, but relatively high in Sively 3 (Table 1).

\section{Natural abundance isotope ratios}

Maximum differences in the $\delta^{15} \mathrm{~N}$ values between the base (detritus) and the top (Macrocotyla or Stygobromus) of the food web were 7.6, 11.4, and $12.6 \%$ in Jones Canyon, Sively 3, and Sively 2, respectively. Leaf and wood $\delta^{15} \mathrm{~N}$ were significantly lower than epilithon $\delta^{15} \mathrm{~N}$ and $>6 \%$ ower than all invertebrates (Fig. 1). In Jones Canyon, the stream without CPOM input, $\delta^{15} \mathrm{~N}$ of FPOM was similar to $\delta^{15} \mathrm{~N}$ of epilithon. In the streams with CPOM input, $\delta^{15} \mathrm{~N}$ of FPOM was inter- 
mediate between CPOM and epilithon. FPOM and epilithon were the likely foods for several taxa (Caecidotea, Dolophilodes, Eurycea, Fontigens, Gyraulus, Gammarus, and Physa sp.) which had $\delta^{15} \mathrm{~N}$ values from 2 to $4 \%$ higher than FPOM and epilithon (Fig. 1). Macrocotyla, S. emarginatus, and S. spinatus had similar $\delta^{15} \mathrm{~N}$ that was $2-4 \%$ o higher than other animals, suggesting they were predators (Fig. 1). Taxa that were present in multiple streams appeared to occupy the same trophic position in each stream.

In Jones Canyon, the stream without CPOM input, natural abundance $\delta^{13} \mathrm{C}$ values were consistent with trophic positions indicated by $\delta^{15} \mathrm{~N}$. Primary consumers (Caecidotea and Fontigens) were $\sim 1 \%$ o $\delta^{13} \mathrm{C}$ enriched relative to epilithon and FPOM. Predators (Macrocotyla, S. emarginatus, and S. spinatus) were $\sim 1 \%$ o $\delta^{13} \mathrm{C}$ enriched relative to primary consumers. Background $\delta^{13} \mathrm{C}$ values were of limited use in clarifying feeding relationships in Sively 3 and Sively 2 because most taxa were $\sim 1 \%$ o more ${ }^{13} \mathrm{C}$ enriched than several potential foods. Thus specific consumer-food pairs could not be distinguished using background $\delta^{13} \mathrm{C}$.

\section{${ }^{13} \mathrm{C}$ uptake and detrital labeling}

Leaves and wood were labeled above background (2-9\%o) only at the uppermost station in Sively 3 and Sively 2. Epilithon, on the other hand, was highly labeled in all three streams by day 28 , and epilithon $\delta^{13} \mathrm{C}$ decreased exponentially downstream (Fig. 2). Epilithon was most highly labeled in Sively 3 , where values were 2 and 7 times higher than in Sively 2 or Jones Canyon, respectively. ${ }^{13} \mathrm{C}$ uptake lengths calculated from epilithon and snail $\delta^{13} \mathrm{C}$ were significantly shorter in Sively 2 than in Sively 3 and Jones Canyon, respectively (Table 2). ${ }^{13} \mathrm{C}$ uptake velocities based on epilithon and snail $\delta^{13} \mathrm{C}$ were 3-40 times higher in Sively 2 than in the other streams (Table 2). Uptake length and uptake velocity calculated using either epilithon or snail $\delta^{13} \mathrm{C}$ were very similar for each stream (Table 2). ${ }^{13} \mathrm{C}$ uptake rate was highest in Sively 2, intermediate in Jones Canyon, and lowest in Sively 3 (Table 2). FPOM was labeled above background, but at a lower level than epilithon, and the label decreased exponentially downstream (Fig. 3). FPOM labeling was highest in Sively 3 where tracer $\delta^{13} \mathrm{C}$ was $2.0-2.5$ times higher than in Sively 2 or Jones Canyon.

In all three streams, epilithon and FPOM were generally more labeled two days after the release was stopped than on the final day of the releases (Fig. 4). By 12 days postrelease, epilithon and FPOM $\delta^{13} \mathrm{C}$ fell to levels equal to or below 28-d values. Mean epilithon turnover time was highest in Sively 2 but was not significantly different among streams (ANOVA, $P>$ $0.05)$. At the end of the additions, $0.8-6.3 \%$ of the ${ }^{13} \mathrm{C}$ added to the streams was retained in epilithon and detritus (Table 3). FPOM accounted for most of the ${ }^{13} \mathrm{C}$ retention in all three streams, followed by epilithon and CPOM.
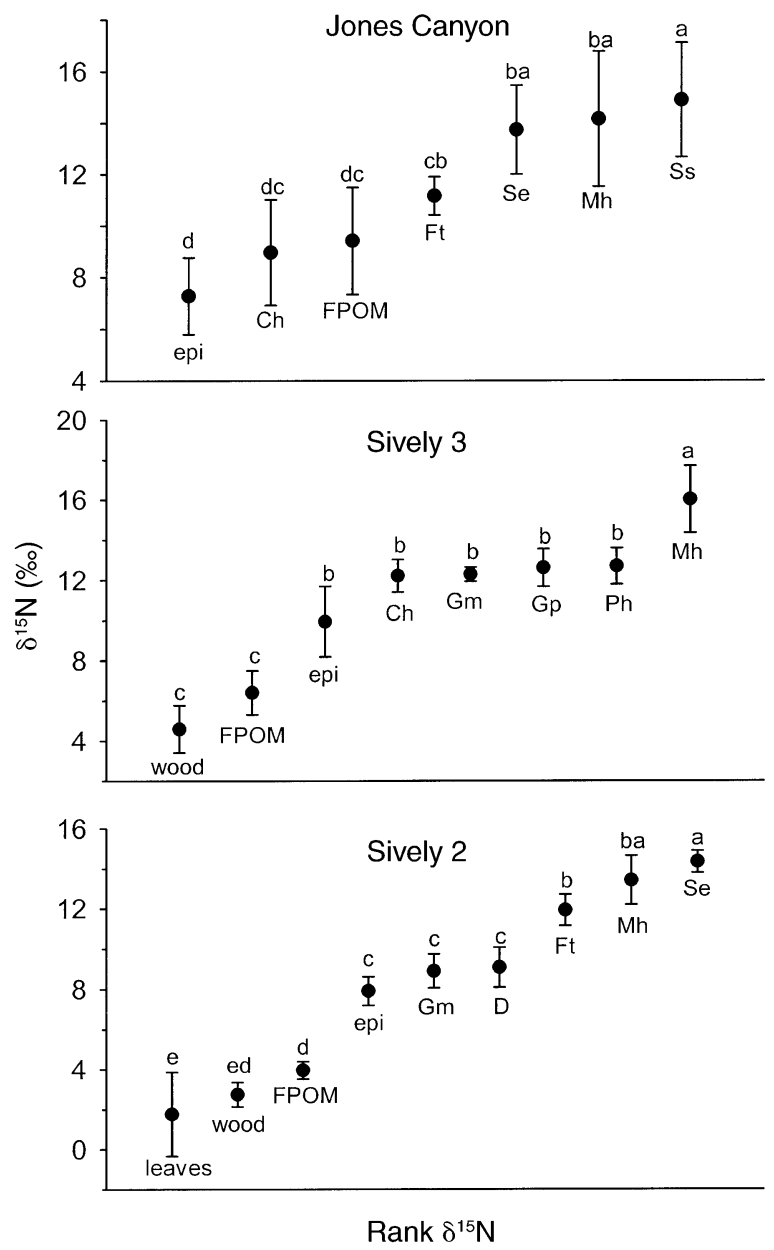

FIG. 1. Natural abundance $\delta^{15} \mathrm{~N}$ values of detritus and animals. Symbols are means ( $n$ ranges from 2 to 18 ) with $95 \%$ confidence intervals. For each stream, bars with the same letter above them are not significantly different (ANOVA, $P<0.05$ ). Abbreviations: epi = epilithon, $\mathrm{Ch}=$ Caecidotea holsingeri, $\mathrm{D}=$ Dolophilodes sp., $\mathrm{Ft}=$ Fontigens tartarea, $\mathrm{Gm}=$ Gammarus minus, $\mathrm{Gp}=$ Gyraulus parvus, $\mathrm{Mh}=$ Macrocotyla hoffmasteri, $\mathrm{Ph}=$ Physa $\mathrm{sp} ., \mathrm{Se}=$ Styobromus emarginatus, and $\mathrm{Ss}=S$. spinatus.

\section{Invertebrate labeling}

All invertebrates were labeled above background, but the magnitude and longitudinal and temporal pattern of ${ }^{13} \mathrm{C}$ enrichment varied among taxa. Dolophilodes was uncommon in the streams, but its $\delta^{13} \mathrm{C}$ at $10 \mathrm{~m}$ in Sively 2 reached $329 \%$, which was $\sim 3$ times the maximum $\delta^{13} \mathrm{C}$ of epilithon at that site. The snails Fontigens, Gyraulus, and Physa were all highly labeled and their longitudinal pattern of labeling was similar to that of epilithon in each stream (Fig. 2). The temporal pattern of Fontigens $\delta^{13} \mathrm{C}$ followed a pattern similar to epilithon: $\delta^{13} \mathrm{C}$ increased to day 30 , then fell to roughly day 28 levels by 12 days postrelease (Fig. 4). Gyraulus and Physa $\delta^{13} \mathrm{C}$ increased or remained roughly the same as day 28 values after the release was stopped (Fig. 4). 


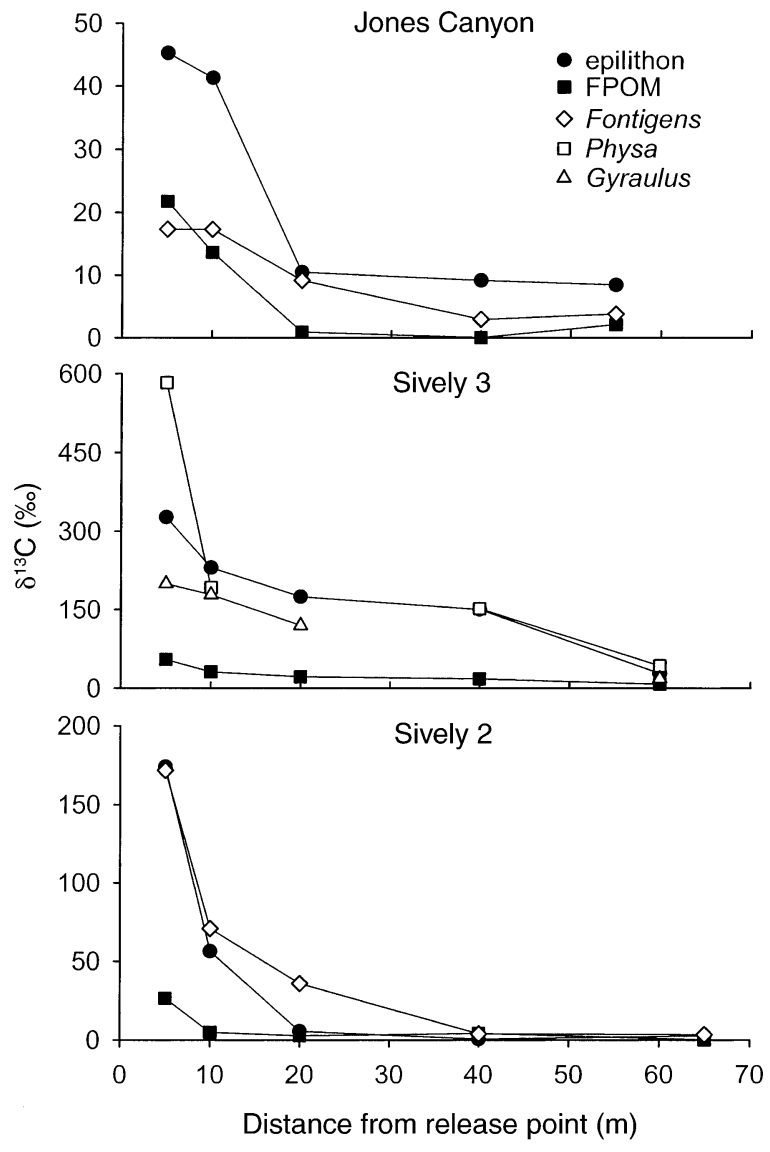

FIG. 2. Tracer $\delta^{13} \mathrm{C}$ in epilithon, FPOM, and snails vs distance from the ${ }^{13} \mathrm{C}$ release point for each stream. Samples are composites collected at each station after 28 days of ${ }^{13} \mathrm{C}$ release.

In both Sively 3 and Sively 2, Gammarus was less enriched than the snails and epilithon. Individuals at the site closest to the release were less labeled than those at downstream stations (Fig. 3). Gammarus $\delta^{13} \mathrm{C}$ values below the upper stations were slightly above
FPOM but below epilithon, suggesting that Gammarus fed on both foods.

$S$. emarginatus was less enriched than Gammarus but followed a roughly similar longitudinal pattern in Sively 2 on day 28 (Fig. 3). Caecidotea, S. spinatus, and Macrocotyla were enriched to slightly lower levels than Gammarus, but these animals were not as well represented in the sampling (Fig. 3). Gammarus, $S$. emarginatus, and $S$. spinatus $\delta^{13} \mathrm{C}$ continued to increase or did not change at most stations up to 12 days postrelease (Fig. 4).

\section{Invertebrate:food tracer $\delta^{13} \mathrm{C}$ ratios}

Fontigens:epilithon and Gyraulus:epilithon tracer $\delta^{13} \mathrm{C}$ ratios were $<1.0$ in Jones Canyon and Sively 3, respectively (Table 4 ). These snails had not yet reached isotopic equilibrium or ate a less enriched food, possibly FPOM. The high Fontigens:epilithon ratio (3.23) in Sively 2 was due primarily to a high Fontigens $\delta^{13} \mathrm{C}$ value at $20 \mathrm{~m}$; the ratio calculated without that site was $1.12 \pm 0.19$ (mean $\pm 1 \mathrm{SE}$ ). Physa:epilithon was close to 1.0 (Table 4), suggesting Physa was primarily consuming epilithon. Ratios of Gammarus to FPOM and to epilithon were nearly identical in Sively 3 and Sively 2 (Table 4 ). Values $>1.0$ for FPOM and $<1.0$ for epilithon are consistent with Gammarus using both foods. Macrocotyla: prey ratios ranged from 0.14 for Physa to 0.88 for Fontigens (Table 4). S. emarginatus: prey and $S$. spinatus: prey ratios were well below 1.0 for all primary consumers (Table 4), suggesting they did not reach isotopic equilibrium during the experiment.

\section{DISCUSSION}

\section{Food web structure}

Animals in Organ Cave streams comprised two trophic levels: primary consumers and predators, both of which rely ultimately on allochthonous DOM that has been retained as epilithic organic matter. Retention may be direct via incorporation into epilithic microbial biomass or indirect via adsorption to biofilms or mineral

TABLE 2. Mean ${ }^{13} \mathrm{C}$ concentration (range in parentheses) at the release point, ${ }^{13} \mathrm{C}$ uptake length for epilithon and snails $\left(S_{\mathrm{w}} ; 95 \% \mathrm{CI}\right.$ in parentheses $),{ }^{13} \mathrm{C}$ uptake velocity $\left(V_{\mathrm{f}}\right)$ calculated from epilithon and snails, ${ }^{13} \mathrm{C}$ uptake rate, and mean epilithon turnover time (1 SE; in parentheses) in each stream.

\begin{tabular}{llcc}
\hline \hline \multicolumn{1}{c}{ Variable } & Jones Canyon & \multicolumn{1}{c}{ Sively 3 } & Sively 2 \\
\hline${ }^{13} \mathrm{C}$ concentration $(\mu \mathrm{g} / \mathrm{L})$ & $1.3(1.0-1.9)^{\mathrm{a}}$ & $1.1(0.1-1.6)^{\mathrm{a}}$ & $1.1(0.5-1.5)^{\mathrm{a}}$ \\
${ }^{13} \mathrm{C} S_{\mathrm{w}}(\mathrm{m})$ & & & \\
$\quad$ Epilithon & $26.7(15.7-89.4)^{\mathrm{a}}$ & $25.7(15.1-87.7)^{\mathrm{a}}$ & $6.3(3.9-16.5)^{\mathrm{b}}$ \\
$\quad$ Snails & $27.7(15.8-100.0)^{\mathrm{a}}$ & $26.6(11.2-69.5)^{\mathrm{a}}$ & $9.7(7.3-14.3)^{\mathrm{b}}$ \\
${ }^{13} \mathrm{C} V_{\mathrm{f}}\left(\times 10^{-5} \mathrm{~m} / \mathrm{s}\right)$ & & \\
Epilithon & 0.6 & 4.6 & 22.8 \\
$\quad$ Snails & 0.5 & 4.5 & 14.8 \\
${ }^{13} \mathrm{C}$ uptake rate $\left(\mathrm{mg} \cdot \mathrm{m}^{-2} \cdot \mathrm{h}^{-1}\right)$ & 0.19 & 0.04 & 0.23 \\
Epilithon turnover time $(\mathrm{d})$ & $10.0(6.6)^{\mathrm{a}}$ & $12.7(3.0)^{\mathrm{a}}$ & $16.7(4.0)^{\mathrm{a}}$ \\
\hline
\end{tabular}

Note: Values within each row with the same superscript letter are not significantly different (ANOVA, $P>0.05$ ). 

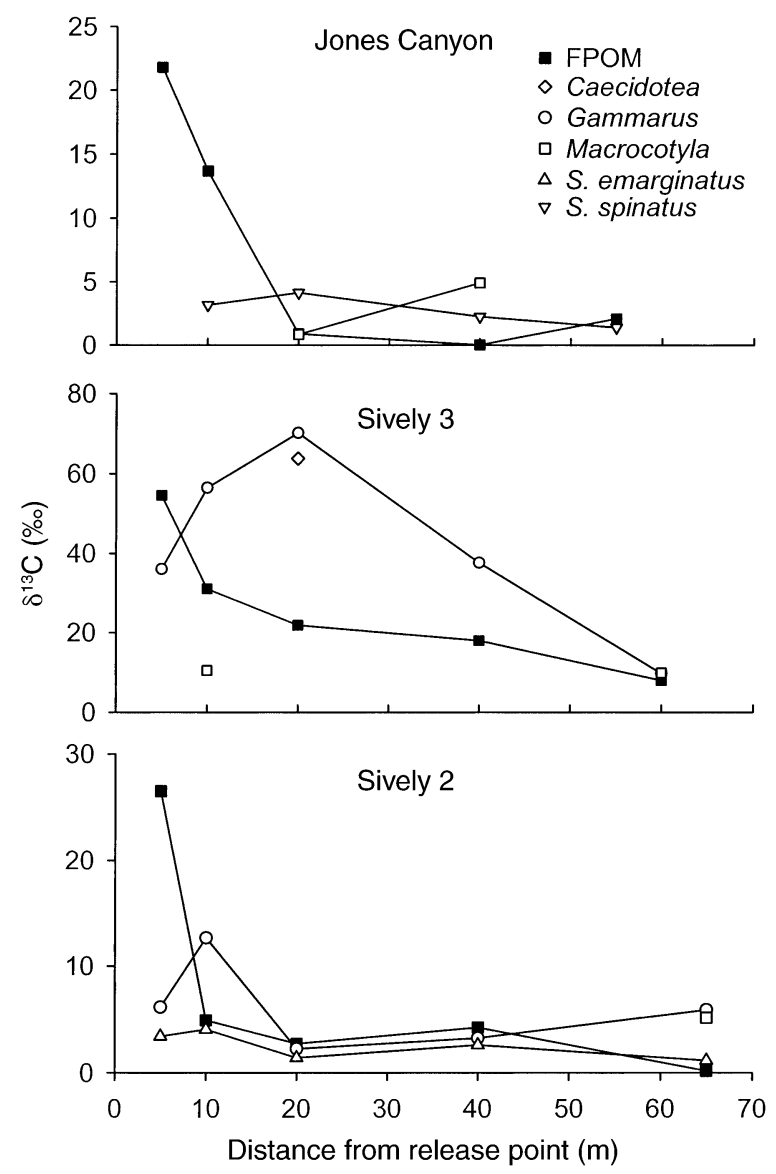

FIG. 3. Tracer $\delta^{13} \mathrm{C}$ in FPOM, primary consumers, and predators vs. distance from the ${ }^{13} \mathrm{C}$ release point for each stream. Samples are composites collected at each station after 28 days of ${ }^{13} \mathrm{C}$ release.

surfaces. Regardless of mechanism, natural abundance $\delta^{15} \mathrm{~N}$ values, high tracer ${ }^{13} \mathrm{C}$ enrichment, and similarity in uptake length and longitudinal pattern to epilithon strongly tied the snails (Fontigens, Gyraulus, and Phy$s a)$ to epilithic biofilms. In addition, snails were only found on rock surfaces in the streams, suggesting FPOM and CPOM were unlikely foods. Like snails, Dolophilodes was highly labeled after 28 days, with a $\delta^{13} \mathrm{C}$ value above epilithon values. Dolophilodes constructs a very fine net capable of filtering bacteria-sized particles (Malas and Wallace 1977), and was probably feeding on suspended bacteria and DOC colloids in the water column that were highly labeled. These caddisflies are commonly found in some Organ Cave streams, but their populations are probably sustained by recruitment from the surface. Even if Dolophilodes does not establish self-sustaining populations, it is participating in the stream food web as a filterer, a niche apparently not occupied by any cave species.

The trophic position of Gammarus in cave and surface streams has been somewhat ambiguous. The surface form of Gammarus is generally considered a fac- ultative shredder, but has a broad diet including leaves, FPOM, suspended particulate organic matter, and biofilms (Haley 1997, Mulholland et al. 2000). The humpshaped tracer profile of Gammarus in our streams is similar to that shown by filter-feeding animals in other tracer studies (e.g., Tank et al. 2000). However, Gammarus was not highly enriched like Dolophilodes, a filter feeder. Gammarus may have fed on enriched and unenriched food at our uppermost station where our tracer may not have been well mixed. Gammarus is also highly mobile and may have fed above and below our addition point near the uppermost station. Tracer ${ }^{13} \mathrm{C}$ results suggest Gammarus fed primarily on FPOM and, to a lesser extent, epilithon. However, Gammarus did not reach equilibrium with its food because its $\delta^{13} \mathrm{C}$ continued to increase after the release was stopped, so we have certainly underestimated Gammarus' reliance on epilithon. The cave form of Gammarus shreds leaves in the laboratory and in cave streams as well (Simon and Benfield 2001). Culver et al. (1991) suggested that Gammarus could be a predator of Caecidotea in Sively 3 and in laboratory streams. Gammarus may be a predator or shredder when prey and leaves are available, respectively, but Caecidotea were rare in our streams and most leaves were small, refractory pieces. Wood was abundant in Sively 2, but neither natural abundance of ${ }^{15} \mathrm{~N}$ nor tracer ${ }^{13} \mathrm{C}$ results suggested a direct link between Gammarus, or any other animals, and wood.

Based on natural abundance $\delta^{15} \mathrm{~N}$, there are three invertebrate predators in Organ Cave streams: Macrocotyla, S. emarginatus, and S. spinatus. We could not clearly discriminate which primary consumers these predators were eating. Gammarus is a likely prey for Macrocotyla and S. emarginatus. The stygophilic planarian Phagocata gracilis feeds on newly hatched $G$. minus (Jenio 1972), and Macrocotyla may do the same in Sively 2 and Sively 3. Culver et al. (1991) suggested that $S$. emarginatus could be a predator of Gammarus in Sively 2. All of the predators were enriched with ${ }^{13} \mathrm{C}$ by the end of our study, indicating that $\mathrm{C}$ from microbial films was passed to predators.

Salamanders in caves have generally been considered to be predators (e.g., Culver 1973) and Eurycea is a predator in surface streams (Burton 1976). The natural abundance $\delta^{15} \mathrm{~N}$ of Eurycea in Sively 3 was more consistent with a detritivore than with a predator. We collected one salamander after $28 \mathrm{~d}$ in Sively 3 and it, like the invertebrates, was labeled (11.2\%o above background). Boluses of detritus and sediment, and the absence of prey, in the guts of other cave salamanders (Gyrinophilus porphyriticus and Haideotriton wallacei) have been interpreted as failed feeding attempts rather than detritus feeding (Culver 1973, Peck 1973). Our sample size is small, but the possibility that $E u$ rycea uses detritus as food in caves should be considered. 

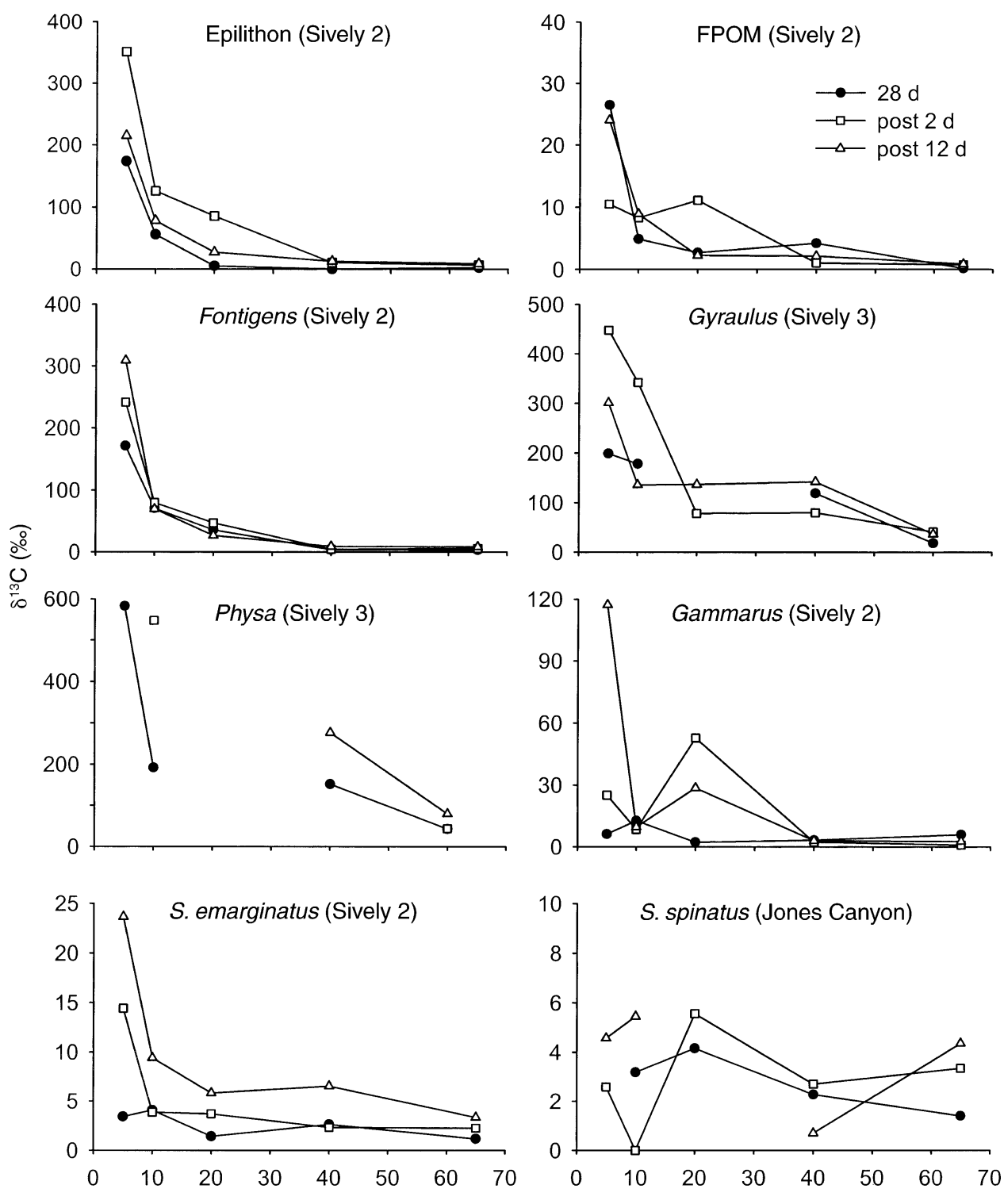

Distance from release point $(\mathrm{m})$

FIG. 4. Tracer $\delta^{13} \mathrm{C}$ in each major compartment after 28 days of ${ }^{13} \mathrm{C}$ release and 2 and 12 days after stopping the release. Samples are composites collected at each station after 28 days of ${ }^{13} \mathrm{C}$ release.

\section{${ }^{13} \mathrm{C}$ acetate uptake and epilithon}

TABle 3. Mass balance of ${ }^{13} \mathrm{C}(\mathrm{mg})$ retained in epilithon, fine particulate organic matter (FPOM), and coarse particulate organic matter (CPOM), and the total ${ }^{13} \mathrm{C}$ added to each study reach.

\begin{tabular}{lcrr}
\hline \hline Variable & $\begin{array}{c}\text { Jones } \\
\text { Canyon }\end{array}$ & \multicolumn{1}{c}{ Sively 3 } & \multicolumn{1}{c}{ Sively 2 } \\
\hline Epilithon & $1.3(1.6)$ & $12.3(0.6)$ & $1.2(0.1)$ \\
FPOM & $4.1(4.8)$ & $64.4(2.9)$ & $6.9(0.6)$ \\
CPOM & $0.0(0.0)$ & $<0.1(0.0)$ & $0.9(0.1)$ \\
Total retained & $5.4(6.3)$ & $76.7(3.5)$ & $9.0(0.8)$ \\
Total added & $85.6(100)$ & $2201.4(100)$ & $1074.4(100)$ \\
\hline
\end{tabular}

Note: Values in parentheses are the percentage of the total ${ }^{13} \mathrm{C}$ added to each stream.
Our tracer experiment showed that epilithon $\mathrm{C}$ is used by consumers and passed on to predators in cave streams, as is true for surface streams (e.g., Hall and Meyer 1998). Because there is no light to support algae in the cave streams, ${ }^{13} \mathrm{C}$ labeling was due to uptake by heterotrophic microbes and abiotic sorption to microbial films. High labeling of epilithic biofilms in caves is not surprising because microbes on rocks should rely heavily on DOC as a carbon supply. Lower labeling of FPOM, compared to epilithon, is probably a result of larger amounts of detrital $\mathrm{C}$ in the sediments, which would not incorporate tracer ${ }^{13} \mathrm{C}$ and dilute the tracer 
TABLE 4. Consumer: potential food $\delta^{13} \mathrm{C}$ ratios on day 28 , corrected for background $\delta^{13} \mathrm{C}$.

\begin{tabular}{|c|c|c|c|}
\hline Site & Consumer & Food & Ratio \\
\hline \multicolumn{4}{|l|}{ Stygobites } \\
\hline \multirow{4}{*}{$\begin{array}{l}\text { Jones Canyon } \\
\text { Sively } 2\end{array}$} & Fontigens & epilithon & $0.49(0.09)$ \\
\hline & Fontigens & epilithon & $3.23(1.26)$ \\
\hline & Macrocotyla & Fontigens & $1.51 \dagger$ \\
\hline & & Gammarus & $0.87+$ \\
\hline \multirow[t]{3}{*}{ Sively 3} & Macrocotyla & Physa & $0.14(0.09)$ \\
\hline & & Gyraulus & $0.30(0.24)$ \\
\hline & & Gammarus & $0.60(0.41)$ \\
\hline \multirow[t]{2}{*}{ Jones Canyon } & Macrocotyla & S. spinatus & $1.19(0.98)$ \\
\hline & & Fontigens & $0.88(0.78)$ \\
\hline \multirow[t]{2}{*}{ Sively 2} & S. emarginatus & Fontigens & $0.19(0.15)$ \\
\hline & & Gammarus & $0.52(0.15)$ \\
\hline Jones Canyon & S. spinatus & Fontigens & $0.44(0.12)$ \\
\hline \multicolumn{4}{|l|}{ Stygophiles } \\
\hline \multirow[t]{2}{*}{ Sively 2} & Gammarus & epilithon & $0.22(0.11)$ \\
\hline & & FPOM & $1.71(0.42)$ \\
\hline \multirow[t]{2}{*}{ Sively 3} & Gammarus & epilithon & $0.27(0.04)$ \\
\hline & & FPOM & $1.71(0.93)$ \\
\hline \multicolumn{4}{|l|}{ Epigean } \\
\hline \multirow[t]{2}{*}{ Sively 3} & Physa & epilithon & $1.29(0.22)$ \\
\hline & Gyraulus & epilithon & $0.68(0.03)$ \\
\hline
\end{tabular}

Notes: Ratios are means of values for each station ( $n$ ranges from 2 to 5); one standard error is reported in parentheses.

$\dagger$ Animals were present at a single station only.

signal. In addition, microbes in the sediments may have used both DOC and particulate organic matter as C sources, resulting in lower labeling. Bacteria in surface stream sediments rely on both stream water DOC and sediment organic matter (Bott et al. 1984). We assumed fungal uptake would be minimal because we added ${ }^{13} \mathrm{C}$ acetate at very low concentrations (Hall and Meyer 1998). Leaves and wood, whose biofilms are dominated by fungi (Weyers and Suberkropp 1996), were not highly labeled in our streams, supporting our assumption about fungal labeling. The small amount of label incorporated by leaves and wood at the upper stations of our streams was probably due to uptake by bacteria on the CPOM. Leaves and wood were not labeled in a similar ${ }^{13} \mathrm{C}$ release in a surface stream (Hall and Meyer 1998).

The ${ }^{13} \mathrm{C}$ uptake lengths, uptake velocity, and uptake rates in the cave streams were similar to those measured in a forested surface stream (Hall and Meyer 1998). Rapid acetate uptake in the cave streams is not surprising considering the scarcity of organic $\mathrm{C}$ in caves. Our measured uptake rates certainly overestimate natural DOC uptake because acetate should be more labile than bulk DOC in stream water. Differences in uptake lengths among the streams may have been due to differences in discharge. However, there were also large differences in uptake velocity, which accounts for varying velocity and depth, suggesting biological demand for the tracer differed among the streams. Differences in uptake velocity were not clearly related to differences in epilithic biomass among the streams. Epilithic biomass may not accurately reflect short-term microbial productivity, which would be more directly related to DOC demand in the streams. Uptake velocity tended to increase as CPOM input to the streams increased. We only have data for three streams, but this trend suggests that CPOM input may have influenced DOM demand in the streams, perhaps by stimulating microbial productivity by adding labile DOM to the streams.

Given our turnover time calculations, epilithon should have reached isotopic equilibrium by the end of our release. The increase in the epilithon label two days after the release stopped was probably due to a change in stream discharge one day prior to our day 28 sampling. Discharge in the streams increased briefly after a storm and returned to base flow on day 27 of the release. The increased discharge would have diluted the tracer prior to our day 28 sampling. We suspect the epilithon $\delta^{13} \mathrm{C}$ values on day 28 reflect that change. Loss of the ${ }^{13} \mathrm{C}$ label from epilithon and FPOM was not rapid. Turnover times in Organ Cave streams (10.0-16.7 d) are slightly longer than that measured in sediments from forested surface streams (e.g., $\sim 5 \mathrm{~d}$, Crocker and Meyer 1987). Abiotic sorption of DOC to biofilms may have occurred (McDowell 1985, McKnight et al. 1992); however, most DOC uptake by sediments is thought to be biotic (Lock and Hynes 1976, Dahm 1981). Some of the ${ }^{13} \mathrm{C}$ taken up by bacteria may have been incorporated into exopolymers, which may have a much longer turnover time than bacteria (Hall and Meyer 1998), rather than respired. Regardless of the mechanism, the acetate-C was immobilized for reasonably long periods in the biofilms, making it available to animals. Immobilization, either biotic or abiotic, of DOC by stream and hyporheic sediments can be high (Fiebig and Lock 1991, Fiebig and Marxsen 1992). If 
bacteria rapidly respire DOC, microbial pathways will be inefficient and should not be important energy sources for higher trophic levels (Pomeroy and Wiebe 1988). Most of the ${ }^{13} \mathrm{C}$ we added to the streams was lost to respiration or downstream transport. However, some of the tracer remained in detritus, primarily FPOM, and to a lesser extent in epilithon. High retention by FPOM was a result of its relatively high standing stock and intermediate ${ }^{13} \mathrm{C}$ labeling.

\section{Role of particulate vs. dissolved organic matter in cave streams}

The food webs in all three streams were quite similar despite differences in CPOM input. In each stream there were two pathways from organic matter to consumers: epilithon to snails and FPOM/epilithon to Gammarus and Caecidotea. One or more predators fed on primary consumers in each stream, but the specific predator-prey pathways were not clear. Leaves and wood were not primary foods for any of the cave stream animals, despite their high abundance in some streams. Leaf and wood $\delta^{15} \mathrm{~N}$ in our streams ( +2 to $+4 \%$ ) were similar to leaf and wood values in surface streams $(-4$ to $+1 \%$; Fry 1991, Mulholland et al. 2000), but the $\delta{ }^{15} \mathrm{~N}$ values for primary consumers $(>+8.9 \%$ ) in all of the cave streams were beyond values expected $(+4$ to $+8 \%$ ) if consumers were feeding on leaves or wood. For all animals in our streams, $\delta^{15} \mathrm{~N}$ was high (8.9$16.0 \%$ ) compared to $\delta^{15} \mathrm{~N}$ of animals in surface streams (range $=\sim 0$ to $8 \%$; Fry 1991). Epilithon and FPOM also were ${ }^{15} \mathrm{~N}$ enriched compared to similar material in surface streams (<4\%o; Fry 1991, Peterson et al. 1993, Mulholland et al. 2000). The $\delta^{15} \mathrm{~N}$ signature of epilithon, FPOM, and animals in the streams is more consistent with a food web based on soil organic matter, which is relatively ${ }^{15} \mathrm{~N}$ enriched (range -4 to $+14 \%$; Peterson and Fry 1987) than with a food web based on terrestrial leaves and wood. DOM in Sively 2 and Sively 3 may be a mix of organic matter leached from soils above the cave and DOM from leaves and wood in the stream (e.g., Meyer et al. 1997). DOM in Jones Canyon must come exclusively from soil or DOM leached from leaves outside the cave because there is no CPOM in the cave stream.

FPOM in Jones Canyon was either directly from soils or was composed of microbial films on inorganic particles, much like epilithon. Natural abundance $\delta^{15} \mathrm{~N}$ and tracer $\delta^{13} \mathrm{C}$ of FPOM was similar to epilithon, indicating it was primarily microbial films. In comparison, natural abundance $\delta^{15} \mathrm{~N}$ indicated that FPOM in Sively 2 and Sively 3 was a mixture of CPOM and DOMderived material. Microbes in Sively 2 and Sively 3 sediments that used DOM from the water column and POM from leaves or wood could explain the intermediate FPOM $\delta^{15} \mathrm{~N}$ value in those streams. Bacteria in surface stream sediments derive $\mathrm{C}$ from both POM and DOM in the water column (Bott et al. 1984). FPOM tracer ${ }^{13} \mathrm{C}$ labeling also was intermediate between epi- lithon, which uses DOM only, and wood. Wood input appears to influence Organ Cave streams indirectly as a source of FPOM rather than being directly consumed by animals. Wood placed in Sively 2, Sively 3, and Jones Canyon broke down slowly and showed no evidence of invertebrate feeding (Simon and Benfield 2001). Leaves may be a patchy resource in space and time that can be used directly by some animals when they are available. Whole leaves placed in Sively 2 and Sively 3 quickly lost mass and were shredded by invertebrates, particularly Gammarus (Simon and Benfield 2001). However, during our study, leaves were only available as small, refractory fragments that were probably nutritionally similar to wood. Leaves placed in Jones Canyon lost mass slowly, at a rate similar to wood (Simon and Benfield 2001). The Jones Canyon food web, which is composed only of stygobites and does not receive CPOM input, apparently is not equipped to efficiently use leaves and wood. While terrestrial detritus may represent a substantial energy input to some cave streams, stygobites may have lost the ability to use these patchy resources in favor of microbial films, which are a more reliable energy source. Other animals, such as Gammarus, may be able to use other foods which are less reliable, but they still are capable of using microbial biofilms for energy

\section{CONCLUSION}

Previous research has shown that sediment organic matter and microorganisms are important foods for cave invertebrates (Ginet 1960, Dickson 1979). Bacteria make up a large portion of the energy requirements of a variety of stream invertebrates (Hall and Meyer 1998). The pattern of ${ }^{13} \mathrm{C}$ uptake and transfer throughout food webs is similar in cave and surface streams, suggesting heterotrophic pathways are similar in the two systems. Although cave streams have fewer species than most surface streams, cave streams contain a similar number of trophic levels and most detrital-based feeding groups (scrapers, collectors, and predators). Our results show that DOM, probably from soils, can help support reasonably complex food webs in streams. Epilithic biofilms and, to a lesser extent, FPOM were the most direct pathways for transfer of DOM to higher trophic levels in the streams. This was true even when CPOM was a large potential source of energy. Similarly, McCutchan and Lewis (2002) showed that algae supported most of the invertebrate production in a shaded surface stream where terrestrial detritus was the dominant organic matter input. Even when biofilms (microbial or algal) have a relatively small biomass in streams, they can be significant sources of energy to stream food webs. This link to a relatively reliable source of carbon, allochthonous DOM, should impart some stability to the cave food web. While CPOM input did not appear to be consistently important as a direct food resource in the cave streams, it may play an important role sporadically or indirectly by providing 
FPOM and labile DOM that may influence microbial activity in the streams.

\section{ACKNOWLEDGMENTS}

We thank S. and J. Morgan for allowing us access to Organ Cave through their property. Members of the Virginia Tech Stream Team assisted in the cave and the laboratory. This research was supported by a National Science Foundation Dissertation Improvement Grant (DEB-9801082) to K. S. Simon and E. F. Benfield, and by supporting grants from Sigma $\mathrm{Xi}$, the National Speleological Society, the Virginia Tech Graduate Student Association and the Biology Department at Virginia Tech. We thank Stuart Findlay, Dev Niyogi, Steve Thomas, and two anonymous reviewers for helpful comments about the manuscript.

\section{Literature Cited}

Bott, T. L., L. A. Kaplan, and F. T. Kuserk. 1984. Benthic bacterial biomass supported by streamwater dissolved organic matter. Microbial Ecology 10:335-344.

Burton, T. M. 1976. An analysis of the feeding ecology of the salamanders (Amphibia urodela) of the Hubbard Brook experimental forest, New Hampshire. Journal of Herpetology 10:187-204.

Crocker, M. T., and J. L. Meyer. 1987. Interstitial dissolved organic carbon in sediments of a southern Appalachian stream. Journal of the North American Benthological Society 6:159-167.

Culver, D. C. 1973. Feeding behavior of the salamander Gyrinophilus porphyriticus in caves. International Journal of Speleology 5:369-377.

Culver, D. C. 1982. Cave life: evolution and ecology. Harvard University Press, Cambridge, Massachusettes, USA.

Culver, D. C. 1985. Trophic relationships in aquatic cave environments. Stygologia 1:43-53.

Culver, D. C., D. W. Fong, and R. W. Jernigan. 1991. Species interactions in cave stream communities: experimental results and microdistribution effects. American Midland Naturalist 126:364-379.

Culver, D. C., W. K. Jones, D. W. Fong, and T. C. Kane. 1994. Organ Cave karst basin. Pages 451-473 in J. Gibert, D. L. Danielopol, J. A. Stanford, and J. H. Thorp, editors Groundwater ecology. Academic Press, San Diego, California, USA.

Cummins, K. W. 1974. Structure and function of stream ecosystems. BioScience 24:631-641.

Dahm, C. N. 1981. Pathways and mechanisms for removal of dissolved organic carbon from leaf leachate in streams. Canadian Journal of Fisheries and Aquatic Sciences 38:6876.

Dickson, G. W. 1979. The importance of cave mud sediments in food preference, growth, and mortality of the troglobitic amphipod crustacean Crangonyx antennatus Packard (Crangonyctidae). Crustaceana 36:129-140.

Fiebig, D. M., and M. A. Lock. 1991. Immobilization of dissolved organic matter from groundwater discharging through the stream bed. Freshwater Biology 26:45-55.

Fiebig, D. M., and J. Marxsen. 1992. Immobilization and mineralization of dissolved free amino acids by stream-bed biofilms. Freshwater Biology 28:129-140.

Fisher, S. G., and G. E. Likens. 1973. Energy flow in Bear Brook, New Hampshire: an integrative approach to stream ecosystem metabolism. Ecological Monographs 43:421439.

Fry, B. 1991. Stable isotope diagrams of freshwater food webs. Ecology 72:2293-2297.

Ginet, R. 1960. Ecologie, écologie et biologie de Niphargus (Amphipodes Gammaridés hypogés). Annales de Biospeologie 15:127-376.
Haley, C. J. 1997. Comparisons of secondary production, life history, and mouthpart functional morphology between two populations of the amphipod Gammarus minus. Dissertation. Virginia Polytechnic Institute and State University, Blacksburg, Virginia, USA.

Hall, R. O., and J. L. Meyer. 1998. The trophic significance of bacteria in a detritus-based stream food web. Ecology 79:1995-2012.

Hall, R. O., B. J. Peterson, and J. L. Meyer. 1998. Testing a nitrogen-cycling model of a forest stream by using a nitrogen-15 tracer addition. Ecosystems 1:283-298.

Hall, R. O., J. B. Wallace, and S. L. Eggert. 2000. Organic matter flow in stream food webs with reduced detrital resource base. Ecology 81:3445-3463.

Hose, L. D., A. N. Palmer, M. V. Palmer, D. E. Northup, P. J. Boston, and H. R. DuChene. 2000. Microbiology and geochemistry in a hydrogen-sulphide-rich karst environment. Chemical Geology 169:399-423.

Jenio, F. 1972. The Gammarus of Elm Spring, Union County, Illinois (Amphipoda:Gammaridiae). Dissertation. Southern Illinois University, Carbondale, Illinois, USA.

Kleinbaum, D. G., L. L. Kupper, and K. E. Muller. 1988. Applied regression analyses and other multivariate methods. Kent, Boston, Massachusetts, USA.

Lock, M. A., and H. B. N. Hynes. 1976. The fate of "dissolved" organic carbon derived from autumn-shed maple leaves (Acer saccharum) in a temperate hard-water stream. Limnology and Oceanography 21:436-443.

Malas, D., and J. B. Wallace. 1977. Strategies for coexistence in three species of net-spinning caddisflies (Trichoptera) in second-order Appalachian streams. Canadian Journal of Zoology 55:1829-1840.

McCutchan, J. H., and W. M. Lewis. 2002. Relative importance of carbon sources for macroinvertebrates in a Rocky Mountain stream. Limnology and Oceanography 47:742752.

McDowell, W. H. 1985. Kinetics and mechanisms of dissolved organic carbon retention in a head water stream. Biogeochemistry 1:329-352.

McKnight, D. M., K. E. Bencala, G. W. Zellweger, G. R. Aiken, G. L. Feder, and K. A. Thorn. 1992. Sorption of dissolved organic carbon by hydrous aluminum and iron oxides occurring at the confluence of Deer Creek and the Snake River, Summit County, Colorado. Environmental Science and Technology 26:1388-1396.

Meyer, J. L. 1994. The microbial loop in flowing waters. Microbial Ecology 28:195-199.

Meyer, J. L., J. B. Wallace, and S. L. Eggert. 1997. Leaf litter as a source of dissolved organic carbon in streams. Ecosystems 0:1-11.

Minshall, G. W., R. C. Petersen, K. W. Cummins, T. L. Bott, J. R. Sedell, C. E. Cushing, and R. L. Vannote. 1983. Interbiome comparison of stream ecosystem dynamics. Ecological Monographs 53:1-25.

Mulholland, P. J., J. L. Tank, D. M. Sanzone, W. M. Wollheim, B. J. Peterson, J. R. Webster, and J. L. Meyer. 2000. Food resources of stream macroinvertebrates determined by natural-abundance stable $\mathrm{C}$ and $\mathrm{N}$ isotopes and a ${ }^{15} \mathrm{~N}$ tracer addition. Journal of the North American Benthological Society 19:145-157.

Newbold, J. D., J. W. Elwood, R. V. O'Neill, and W. VanWinkle. 1981. Measuring nutrient spiraling in streams. Canadian Journal of Fisheries and Aquatic Sciences 38: 860-863.

Newell, S. Y. 1984. Bacterial and fungal productivity in the marine environment: a contrastive overview. Colloques Internationaux Centre National Recherches Scientifique (Marseilles) 331:133-139.

Peck, S. B. 1973. Feeding efficiency in the cave salamander 
Haidetriton wallacei. International Journal of Speleology 5:15-19.

Peterson, B. J., M. Bahr, and G. W. Kling. 1997. A tracer investigation of nitrogen cycling in a pristine tundra river. Canadian Journal of Fisheries and Aquatic Sciences 54: 2361-2367.

Peterson, B. J., and B. Fry. 1987. Stable carbon isotopes in ecosystem studies. Annual Review of Ecology and Systematics 18:293-320.

Peterson, B., B. Fry, L. Deegan, and A. Hershey. 1993. The trophic significance of epilithic algal production in a fertilized tundra river ecosystem. Limnology and Oceanography 38:872-878.

Pomeroy, L. R., and W. J. Wiebe. 1988. Energetics of microbial food webs. Hydrobiologia 159:7-18.

Post, D. M. 2002. Using stable isotopes to estimate trophic position: models, methods, and assumptions. Ecology 83: 703-718.

Rounick, J. S., M. J. Winterbourn, and G. L. Lyon. 1982. Differential utilization of allochthonous and autochthonous inputs by aquatic invertebrates in some New Zealand streams: a stable carbon isotope study. Oikos 39:191-198.

Sarbu, S. M., T. C. Kane, and B. K. Kinkle. 1996. A chemoautotrophically based cave ecosystem. Science 272: $1953-1955$.
Simon, K. S., and E. F. Benfield. 2001. Leaf and wood breakdown in cave streams. Journal of the North American Benthological Society 20:550-563.

Stevens, P. J. 1988. Caves of the Organ Cave plateau, Greenbrier County, West Virginia. Bulletin Number 9, West Virginia Speleological Survey, Barrackville, West Virginia, USA.

Stream Solute Workshop. 1990. Concepts and methods for assessing solute dynamics in stream ecosystems. Journal of the North American Benthological Society 9(2):95-119.

Tank, J. L., J. L. Meyer, D. M. Sanzone, P. J. Mulholland, J. R. Webster, B. J. Peterson, W. M. Wolheim, and N. E. Leonard. 2000. Analysis of nitrogen cycling in a forested stream during autumn using a $15 \mathrm{~N}$-tracer addition. Limnology and Oceanography 45:1013-1029.

Vannote, R. L., G. W. Minshall, K. W. Cummins, J. R. Sedell, and C. E. Cushing. 1980. The river continuum concept. Canadian Journal of Fisheries and Aquatic Sciences 37: 130-137.

Wallace, J. B., S. L. Eggert, J. L. Meyer, and J. R. Webster. 1999. Effects of resource limitation on a detrital-based ecosystem. Ecological Monographs 69:409-442.

Weyers, H. S., and K. Suberkropp. 1996. Fungal and bacterial production during the breakdown of yellow poplar leaves in 2 streams. Journal of the North American Benthological Society 15:408-420. 